Acta Protozool. (2016) 55: 249-257

www.ejournals.eu/Acta-Protozoologica

doi:10.4467/16890027AP.16.027.6096

PROTOZOOLOGICA

\title{
Trichodinids (Ciliophora) of Corydoras paleatus (Siluriformes) and Jenynsia multidentata (Cyprinodontiformes) from Argentina, with Description of Trichodina corydori n. sp. and Trichodina jenynsii n. sp.
}

\author{
Paula S. MARCOTEGUI ${ }^{1}$, Linda BASSON ${ }^{2}$, and Sergio R. MARTORELLI ${ }^{1}$ \\ ${ }^{1}$ Centro de Estudios Parasitológicos y de Vectores (CEPAVE) (CCT-La Plata-CONICET-UNLP), Argentina; ${ }^{2}$ Department of \\ Zoology and Entomology, University of the Free State, Bloemfontein, Republic of South Africa
}

\begin{abstract}
During surveys of parasites of the pepper cory Corydoras paleatus Jenyns, 1842 and sided-livebearer Jenynsia multidentata Jenyns, 1842 from Samborombón River, Argentina, Trichodina corydori n. sp., Trichodina cribbi Dove and O’Donoghue, 2005 and T. jenynsii $\mathrm{n}$. sp. were morphologically studied. Taxonomic and morphometric data for these trichodinids based on dry silver nitrate-impregnated specimens are presented. Trichodina corydori is characterized by a prominent blade apophysis, the section connecting the blade and central part is short, and the adoral ciliary spiral makes a turn of $370-380^{\circ}$. Trichodina jenynsii is characterized by curved blades and prominentlyshaped denticle rays that are characteristically extremely long, tapering to thin sharp points in adult specimens. This study is the first formal report of these trichodinids from South America, and the description of two new species.
\end{abstract}

Key words: Ciliophora, Trichodina, fish parasites, gill parasites, trichodinids, Argentina.

\section{INTRODUCTION}

Trichodinid ciliophorans have rarely been studied in South America (Martins and Ghiraldelli 2008, Miranda et al. 2012, Hashimoto et al. 2016). Several authors reported Trichodina spp. from Argentina, but formal descriptions were not made (Viozzi 1996, Cremonte and Figueras 2004, Cremonte et al. 2005). The only single marine species formally described from Argentinian waters is Trichodina marplatensis Martorelli, Marcotegui et Alda, 2008, found on the ctenophore Mnemiopsis

Address for correspondence: Paula S. Marcotegui, Boulevard 120, No. 1460 e/61 (B1902CHX) La Plata, Buenos Aires, Argentina. Phone: 054-221-4233471; Fax: 054-221-4232327; e-mail: pmarcotegui@hotmail.com mccradyi (Mayer) (Martorelli et al. 2008). Marcotegui and Martorelli (2009) described Trichodina scalensis Marcotegui et Martorelli, 2009 from Mugil liza (Valenciennes), and reported Trichodina puytoraci Lom, 1962, T. lepsii Lom, 1962, T. jadranica (Raabe, 1958) from the same host, and T. murmanica Polyanski, 1955, Diparitella simpex Raabe, 1959 from Micropogonias furnieri (Desmarest) from brackish-waters. Thus far no trichodinids have been described from freshwater fish in Argentina.

The pepper cory, Corydoras paleatus (Jenyns) is native of southern Brazil, Uruguay, Paraguay and Argentina, inhabiting rivers, tributaries and standing waters including pools and small lakes. This species is a very good choice for the community aquarium, because it is a hardy, good looking, and peaceful fish. 
The one-sided livebearer Jenynsia multidentata (Jenyns) is a viviparous fish, showing the broadest distribution of its genus, ranging from the Atlantic coastal drainages from the Rio Negro Province (Argentina) to the city of Rio de Janeiro, Brazil (Ghedotti and Weitzman 1996).

The aim of this paper is to report on three species of trichodinids from freshwater C. paleatus and J. multidentata, and to describe two new species from both these hosts collected in the Samborombón River (Buenos Aires, Argentina). Furthermore, the present communication reports on the morphological characteristics based on silver nitrate-impregnated preparations of these species.

\section{MATERIALS AND METHODS}

Fish were collected from the Samborombón River (Buenos Aires, Argentina) $\left(35^{\circ} 10^{\prime} 39.79^{\prime \prime} \mathrm{S}\right.$ and $\left.58^{\circ} 15^{\prime} 29.70^{\prime \prime} \mathrm{W}\right)$ between April 2013 and August 2013. A total of 32 specimens of C. paleatus and 25 specimens of $J$. multidentata were examined. Skin and excised gills from freshly killed fish were examined under a dissecting microscope. Fresh skin and gill smears were made from the hosts. Smears with trichodinids were air dried and Foissner's modifications of Klein's dry silver nitrate technique (Foissner 1992) was used to impregnate the specimens to study the adhesive disc and its elements. The sequence and method of the description of denticle elements follow the recommendations of Lom (1958) and Van As and Basson (1992). Live specimens, stained with methylene blue or orcein, were used for nuclear observations and details of the infraciliature. Examinations of prepared slides were made with a Olympus BX51 microscope and the measurements were made with Image J software. The photomicrographs were taken using a microscope at $100 \times$ magnification

The description of each species is based on 20 stained and mounted specimens. All measurements are presented in micrometres; minimum and maximum values are given, followed in parentheses by the arithmetic mean and standard deviation. In case of number of denticles and radial pins per denticle, minimum and maximum values are given, followed in parentheses by the mode. The span of the denticle is measured from the tip of blade to the tip of the ray. Body diameter is measured as the adhesive disc plus border membrane. The type and voucher materials have been deposited in the Museo de La Plata, Argentina, Invertebrate Collection (MLP, coll. Nos. MLP000 to MLP000).

\section{RESULTS}

\section{Trichodina corydori $\mathrm{n}$. sp. (Figs 1A-D; 4A)}

Description. A small to medium-sized, freshwater trichodinid: body diameter, 33.9-42.3 (38.1 \pm 2.5$)$; ad- hesive disc diameter, 27.7-37.0 (32.1 \pm 2.6$)$; diameter of denticulate ring, 16.2-23.3 (20.4 \pm 1.7$)$; width of border membrane, 1.8-3.3 (2.9 \pm 0.4$)$; denticle number, 23-27 (24); number of radial pins per denticle, 8-10 (10); denticle span, 8.0-10.7 (9.2 \pm 0.7$)$; denticle length, 2.8-4.7 (3.8 \pm 0.6$)$; central zone of adhesive disc dark; blade length, 3.4-4.4 (3.8 \pm 0.2$)$. Anterior blade margin strongly rounded, curving into very prominent blade apophysis. Distal margin of blade rounded with blade filling most of space between Y-axes. Distal blade margin with strong curve towards blunt and rounded tangent point. Apex of blade not touching $\mathrm{Y}+1$ axis. Posterior blade margin shallow, becoming deeper towards central part. Section connecting the blade and central part short, but well developed. Central part well developed with rounded tip, fitting tightly into preceding denticle. Central part extending more than halfway to Y-1 axis. Shape of central part above and below the

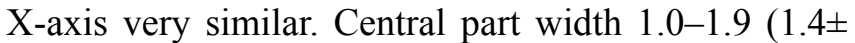
0.3 ). Rays strongly developed, starting more narrow from central part, becoming slightly thicker towards proximal ends. Some rays directed towards center of adhesive disc, some angled slightly anteriorly. Ray apophysis not visible. Ray connection not well developed. Point of ray bluntly and strongly rounded. Ray length $3.5-5.1$ (4.2 \pm 0.4$)$. Ratio of denticle above to denticle below $\mathrm{x}$ axis $0.8-1$. Adoral ciliary spiral makes a turn of $370-380^{\circ}$. Macronucleus horseshoe-shaped, elongated, external diameter is $30.7-34.3(32.5 \pm 1.8)$, distance between ends 6.2-7.7 (7.1 \pm 0.6$)$. Micronucleus not observed.

Type host: Corydoras paleatus Jenyns, 1842 (Siluriformes: Callichthyidae)

Type locality: Samborombón River (Brandsen), Buenos Aires, Argentina (35¹0'39.79"S, $58^{\circ} 15^{\prime} 29.70^{\prime \prime} \mathrm{W}$ )

Site of infection: gills

Type specimens: MLP-Pr 98

Etymology: The specific epithet "corydori" is coined from the name of host species.

Remarks. Morphological features of specimens found in C. paleatus agree with typical for Paratrichodina. Thus, denticles have well-developed rays, and are wedged together only by central parts, if anterior projection present, is situated near the base of the blade and is not in contact with the notch in the blade of the preceding denticle (Lom 1958, Basson and Van As 1989). Lom and Haldar (1976) state that the upper limits of the adoral cilia in Trichodinella Šrámek-Hušek, 1963, Tripartiella Lom, 1959 and Paratrichodina are $290^{\circ}$, and 

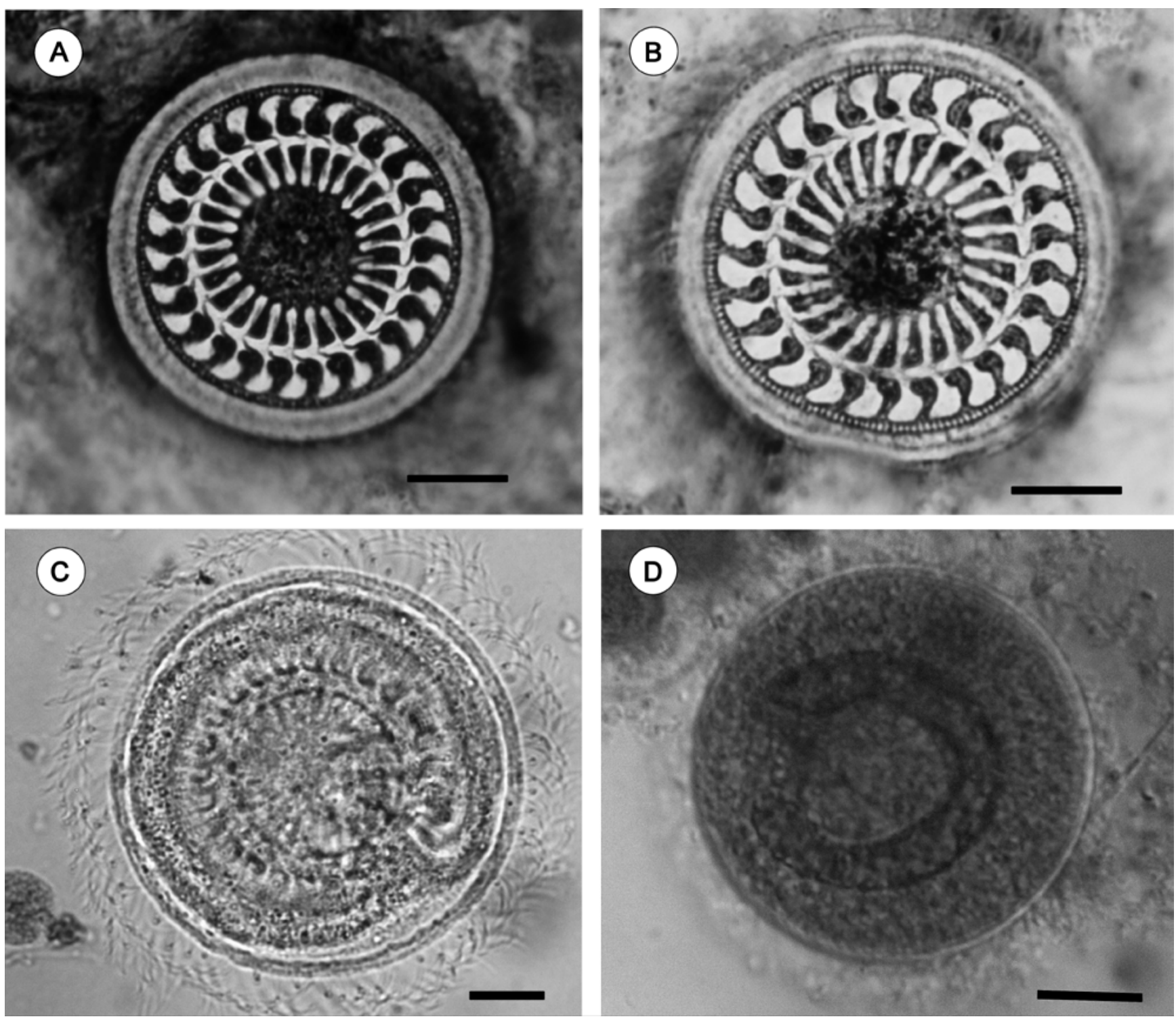

Fig. 1. Photomicrographs of Trichodina corydori n. sp. from Corydoras paleatus. A-B - Silver nitrate-impregnated adhesive discs. C - Methylene-blue staining of adoral ciliary spiral. D - and orcein stain of macronucleus. Scale bars: $10 \mu \mathrm{m}$.

the lower limit in Trichodina is $330^{\circ}$. Nevertheless, the importance of the length of the adoral cilia as a generic characteristic sometimes appears to be less distinct than previously thought. Recently the majority of described species have in effect been classified based on denticle morphology alone (Gaze and Wootten 1999). The adoral spiral in T. corydori $\mathrm{n}$. sp. presents a turn of more than $330^{\circ}$, which falls in the range for Trichodina.

The denticle shape of $T$. corydori mostly resembles Paratrichodina africana Kazubski and El-Tantawy, 1986 recently reported from wild and farmed Oreochromis niloticus (Linnaeus) in eastern Amazonia, Brazil by
Tavares-Dias et al. (2013). However, T. corydori differs from $P$. africana in the shape of the denticle, some other measurements, as well as the adoral spiral: (1) The new species is larger than $P$. africana, for example, in the adhesive disc (27.7-37.0 vs. 12.2-25), and denticulate ring (16.2-23.3 vs. 5.7-16.5). (2) In the case of the new species, the ray length is similar to blade length, but in the case of $P$. africana the ray is shorter than the blade. (3) The ray is thicker in the new species than in P. africana. (4) The section connecting the blade and the central part is very short in the new species, but long in P. africana. (5) The morphometric data of the new species also vary 
when compared to those of $P$. africana, e.g., blade length (3.4-4.4 vs. $1.5-3.8)$, ray length (3.5-5.1 vs. $0.5-2.1$, denticle span (8.0-10.7 vs. 2.9-5.5).

This is the first report of a trichodinid from C. paleatus.

\section{Trichodina cribbi Dove and O'Donoghue, 2005 (Figs 2A-B; 4B)}

Description. Medium-sized, freshwater trichodinid: body diameter, 49.5-69.8 (61.4 \pm 6.6$)$; diameter of adhesive disc, 40.5-59.9 (51.2 \pm 5.8$)$; denticulate ring diameter, 24.6-37.8 (32.8 \pm 3.8$)$; width of border membrane 4.0-5.6 (4.9 \pm 0.6$)$; denticle number, 27-37 (33); number of radial pins per denticle, 9-11(11); denticle span, 11.1-15.3 (13.7 \pm 1.1$)$; denticle length, 3.6-6.0 (5.2 \pm 0.8$)$; centre of adhesive disc clear with clear rounded or slightly notched perimeter containing a few to a large number of dark granules, rarely forming patches; blade length, 5.1-6.4 (5.8 \pm 0.5$)$. Anterior blade margin slants gradually downwards towards apex, touching $\mathrm{Y}+1$ axis. Apex rounded. Blade apophysis not visible. Distal blade margin higher than tangent point. Tangent point delicate. Posterior blade margin strongly curved and L-shaped, deepest point on same level as apex. Posterior projection weakly developed, but present. Section connecting blade and central part robust, clearly distinguishable from blade. Central part squat and well developed with rounded tip, fitting tightly into preceding denticle, extends halfway to Y-1. Central part above and below the $\mathrm{X}$-axis not similar, section above with slanted edge, whilst section below more angular in shape. Central part width is $2.1-3.5(2.8 \pm 0.4)$. Prominent indentation present in lower central part. Section connecting central part and ray very robust. Rays strongly developed, irregular in shape, tapering sharply to a rounded point. Rays prominently curved posteriorly, directed towards Y-1 axis with ends crossing Y-1 axis. Ray apophysis not observed. Ray length 3.5-6.1 (4.7 \pm 0.7$)$. Ratio of denticle above to denticle below $\mathrm{x}$ axis more than one (1.2-1.3). Nuclear apparatus and adoral cilia not observed.

Host: Jenynsia multidentata Jenyns, 1842 (Cyprinodontiformes: Anablepidae)

Locality: Samborombón River (Brandsen), Buenos Aires, Argentina $\left(35^{\circ} 10^{\prime} 39.79^{\prime \prime} \mathrm{S}, 58^{\circ} 15^{\prime} 29.70^{\prime \prime} \mathrm{W}\right)$

Site of infection: gills, skin and fins

Voucher specimens: MLP-Pr100

Remarks. Trichodina cribbi Dove and O'Donoghue, 2005 is characterized by a large circular central inclusion and approximately 28 denticles and with a blade length slightly greater than the ray length. The morphometric characteristics of specimens studied here correspond well with $T$. cribbi as provided by Dove and O’Donoghue (2005).

This species was originally described by Dove and O'Donoghue (2005) from gills of fishes of the Black
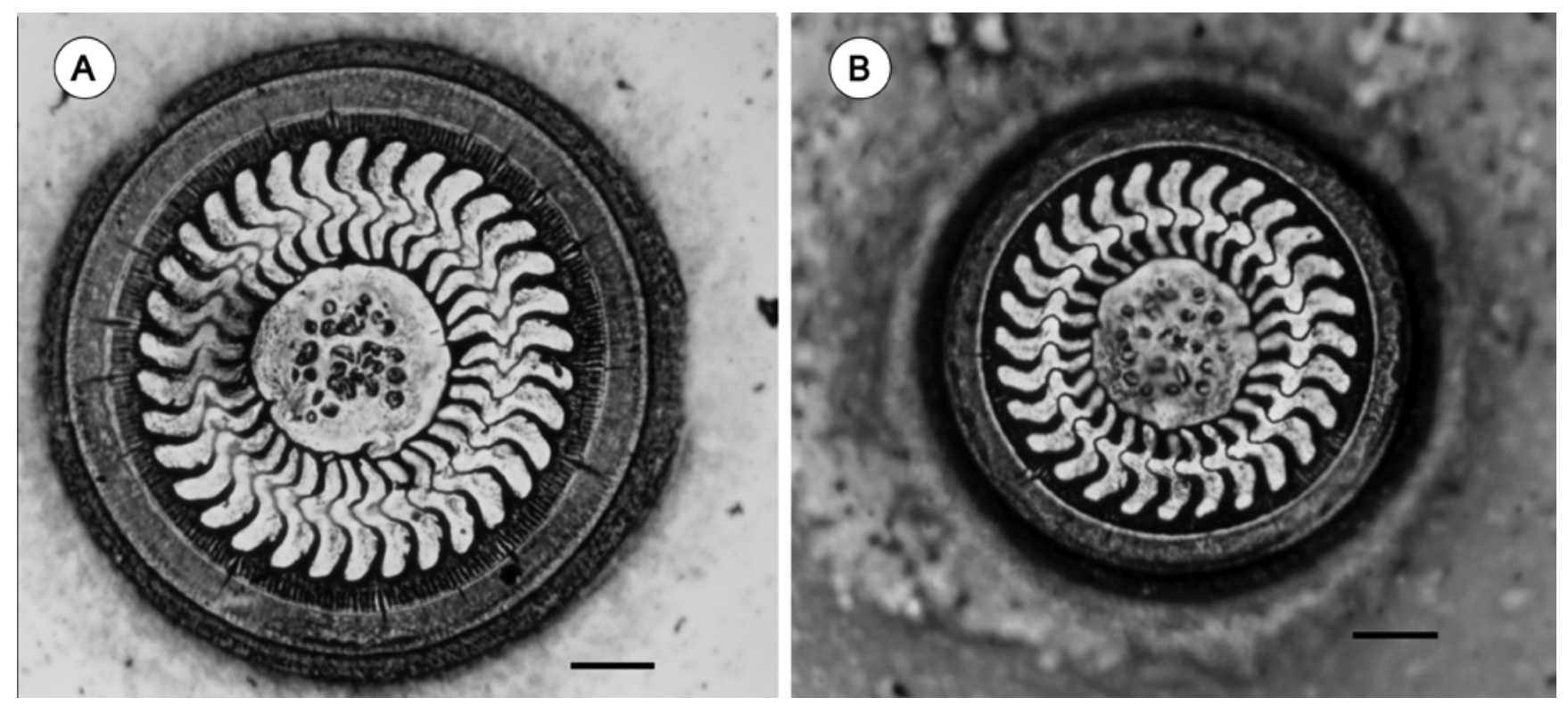

Fig. 2. Photomicrographs of silver nitrate-impregnated adhesive discs of trichodinids from Jenynsia multidentata. A-B - Photomicrographs of Trichodina cribbi. Scale bars: $10 \mu \mathrm{m}$. 
Mountain Peninsula, Lake Burley, Griffin, and Canberra, Australia. Nevertheless, in C. paleatus during this study, T. cribbi was found also on the skin and fins.

This is the second report of this species worldwide, the first record from the Americas and from a new position on the host. The present report also expands on the host range, adding a new host family.

\section{Trichodina jenynsii n. sp. (Figs 3A-D, 4C; Table 1)}

Description. Medium to large freshwater trichodinid: body diameter, 62.6-76.3 (65.5 \pm 4.5$)$; adhesive disc
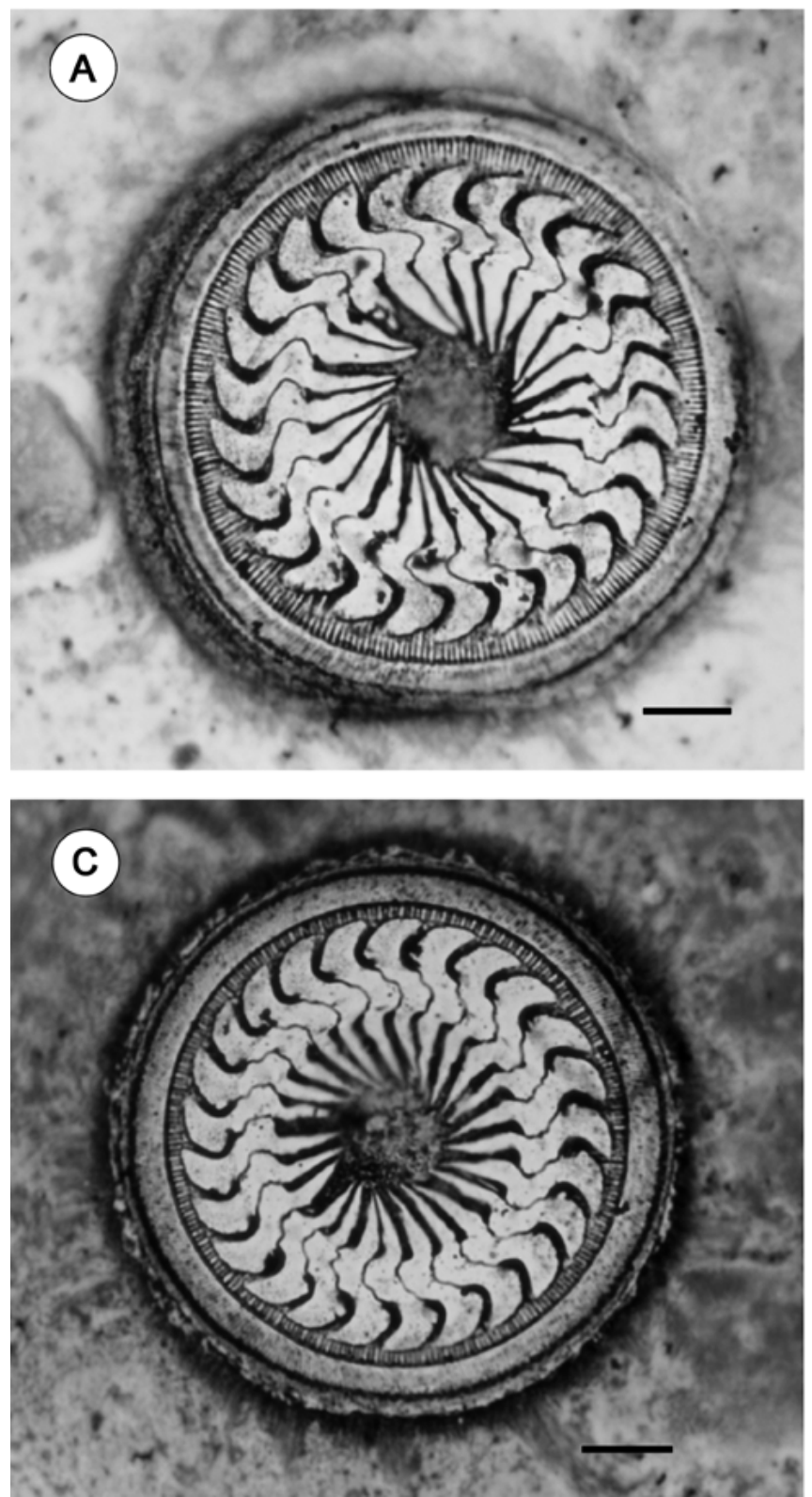

diameter, 54.6-66.9 (57.8 \pm 3.9$)$; denticulate ring diameter, 29.9-41.5 (34.3 \pm 3.6$)$; width of border membrane, 2.8-6.7 (4.4 \pm 1.2$)$; denticle number, 23-26 (25); number of radial pins per denticle, 14-16 (16); denticle span,

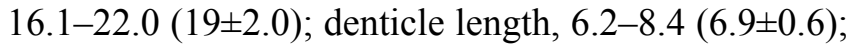
central zone of adhesive disc dark; blade length, 4.77.7 (5.9 \pm 0.9$)$. Blade large, filling large part of space between Y-axes. Distal blade margin almost parallel to border membrane, where-after it slants sharply towards apex. Tangent point narrow, almost on same level as
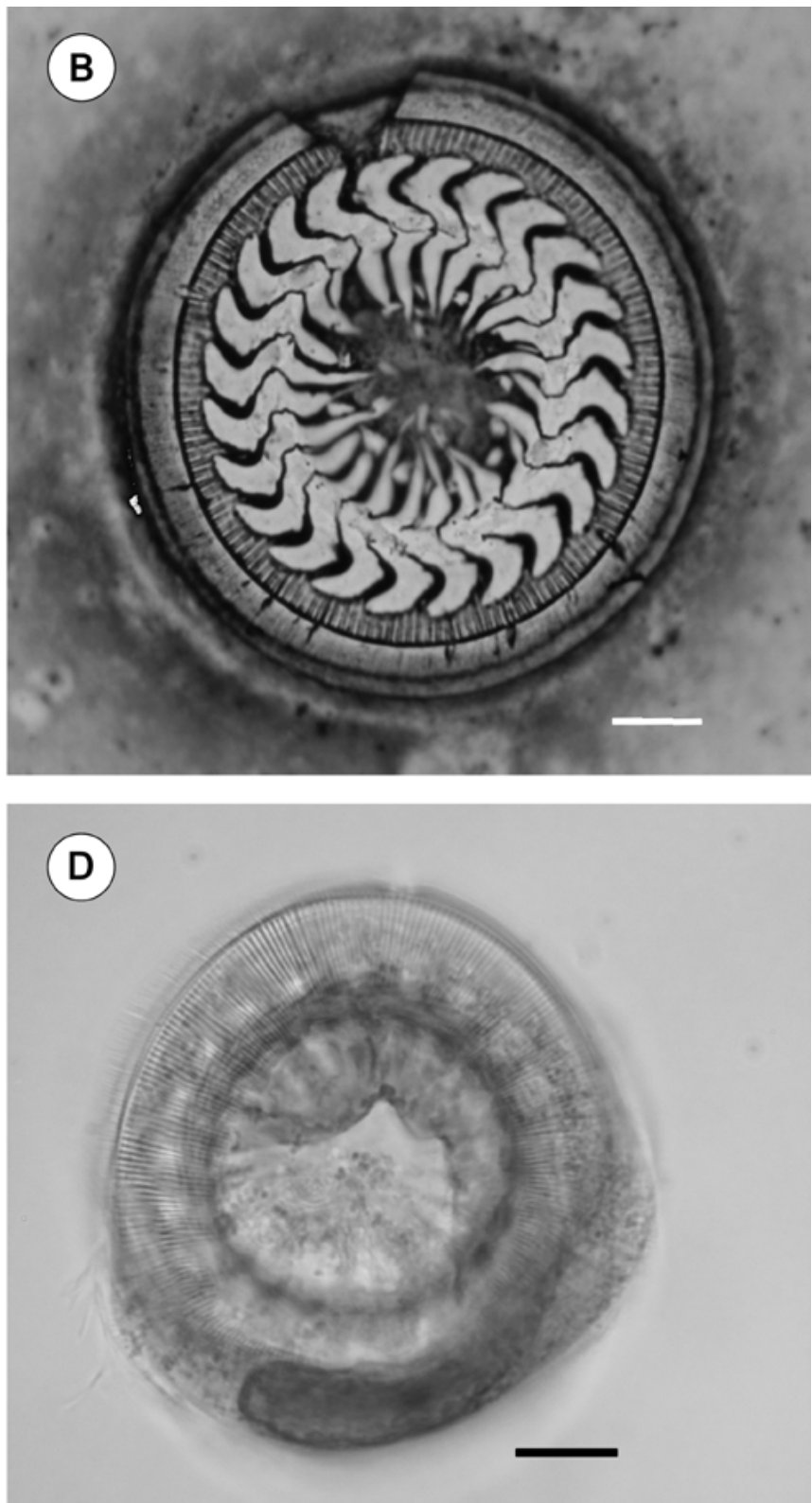

Fig. 3. Photomicrographs of Trichodina jenynsii n. sp. from Jenynsia multidentata. A-C - Adhesive disc after dry silver impregnation. D-Macronucleus with methylene-blue staining. Scale bars: $10 \mu \mathrm{m}$. 

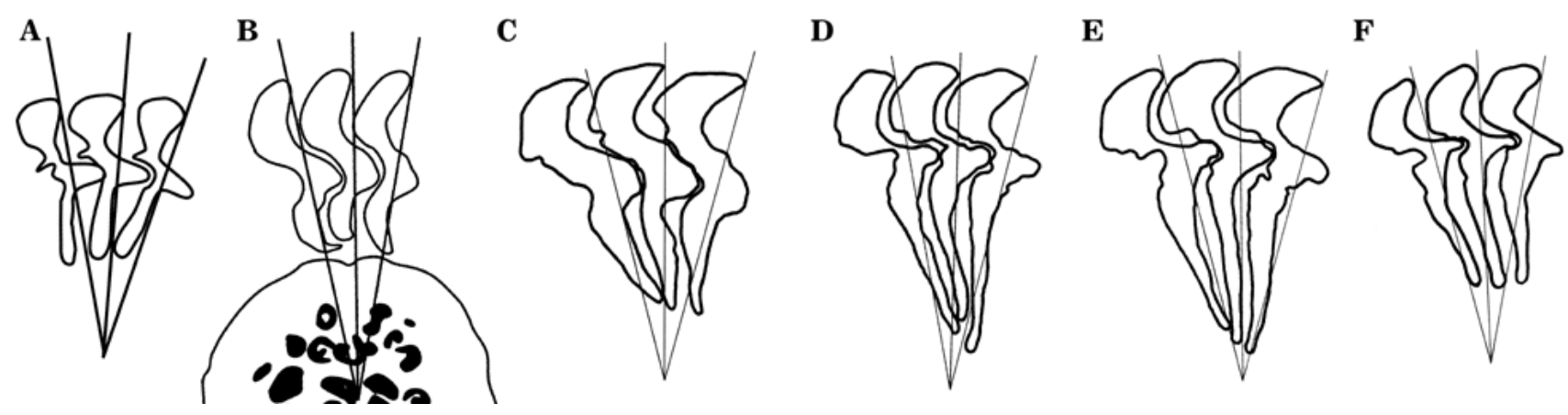

Fig. 4. Diagrammatic drawings of denticles of trichodinids. A - Trichodina corydori $\mathrm{n}$ sp. from Corydoras paleatus. B - T. cribbi from Jenynsia multidentata. C - T jenynsii $\mathrm{n}$ sp. from J. multidentata. D - T. pediculus redrawn from Kazubski and Migala (1968). E - T. pediculus redrawn from Gaze and Wooten (1998). F - T. pediculus redrawn from Kazubski (1991c).

distal margin. Apex of blade prominent, extending beyond Y-axes and clearly distinguishable from anterior blade margin. Anterior blade margin with a prominent apex that shows a clear notch proximal to apex in most denticles of some specimens. Notch present in all specimens, but not equally prominent in all. Blade apophysis present. Posterior blade margin deeply rounded, mostly L-shaped with deepest point lower or at same level as blade apex. Posterior projection well developed, present in majority of denticles. Section connecting blade and central part robust, indistinguishable from thinnest part of blade. Central part well developed, characteristically squat and short, with broadly rounded point that fits tightly into preceding denticle. Central part extends halfway to Y-1 axis. Shape of central part above and below X-axis not similar, upper part with indentation, slanting towards posterior projection, with lower portion more angular. Central part, 3.8-5.7 (4.3 \pm 0.6$)$ wide. Section connecting central part and ray very robust. Ray apophysis present, but weakly developed. Ray base projecting from ray connection very robust. Ray tapers rapidly to a narrow, rounded point. Rays strongly developed and prominent, but show irregularities in shape and in smoothness along their length, as well as in amount of slanting. Some rays prominently slanted posteriorly, others slanted anteriorly, all crossing $\mathrm{Y}$ axes (either $\mathrm{Y}-1$ or $\mathrm{Y}+1$ respectively), while others are straight, either running along Y-axes or between them. No matter the angle of rays, all are straight, none showing a curved nature. Ray length, 6.8-11.5 (8.7 1.6$)$. Ratio of denticle above to denticle below X axis less than 1 (0.66-0.69). Macronucleus horseshoe-shaped, external diameter 43.7-45.4 (44.5 \pm 0.9$)$. Adoral ciliary spiral $380-410^{\circ}$.
Host: Jenynsia multidentata Jenyns, 1842 (Cyprinodontiformes: Anablepidae)

Locality: Samborombón River (Brandsen), Buenos

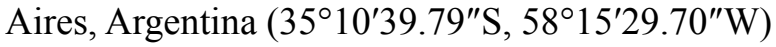

Site of infections: skin

Type specimens: MLP-Pr 100

Etymology: The specific epithet "jenynsii" is coined from the name of host species.

Remarks. Trichodina jenynsii $\mathrm{n}$. sp. shows some similarities with $T$. pediculus Ehrenberg, 1838. Trichodina pediculus is a cosmopolitan species reported from a broad range of hosts, including coelenterates, amphibians and fishes. The distinguishing features of T. pediculus are the curved blades and prominentlyshaped denticle rays that are characteristically extremely long, tapering to thin sharp points in adult specimens. Trichodina jenynsii shows some morphometric and denticle shape similarities that correspond with $T$. pediculus, but also shows clear and conspicuous differences.

Most populations of T. pediculus are much smaller in overall body dimensions than $T$. jenynsii. In Table 1 various populations of $T$. pediculus where silver impregnation was used, are presented, i.e. that of Raabe (1959), Kazubski and Migala (1968), Lom (1970), Kazubski (1991a, b, c), Grupcheva and Sedlaczek (1993) and Gaze and Wootten (1998). The only exception is for the population of Lom (1970) described from hydras from Japan where the upper limit of the adhesive disc diameter is equal to that of $T$. jenynsii. However, the mean is still much smaller (i.e. $49 \mu \mathrm{m}$ for T. pediculus from hydras versus $57.8 \mu \mathrm{m}$ for $T$. jenynsii). The same applies to other body dimension between these two species (see Table 1). We doubt the accurate identification 


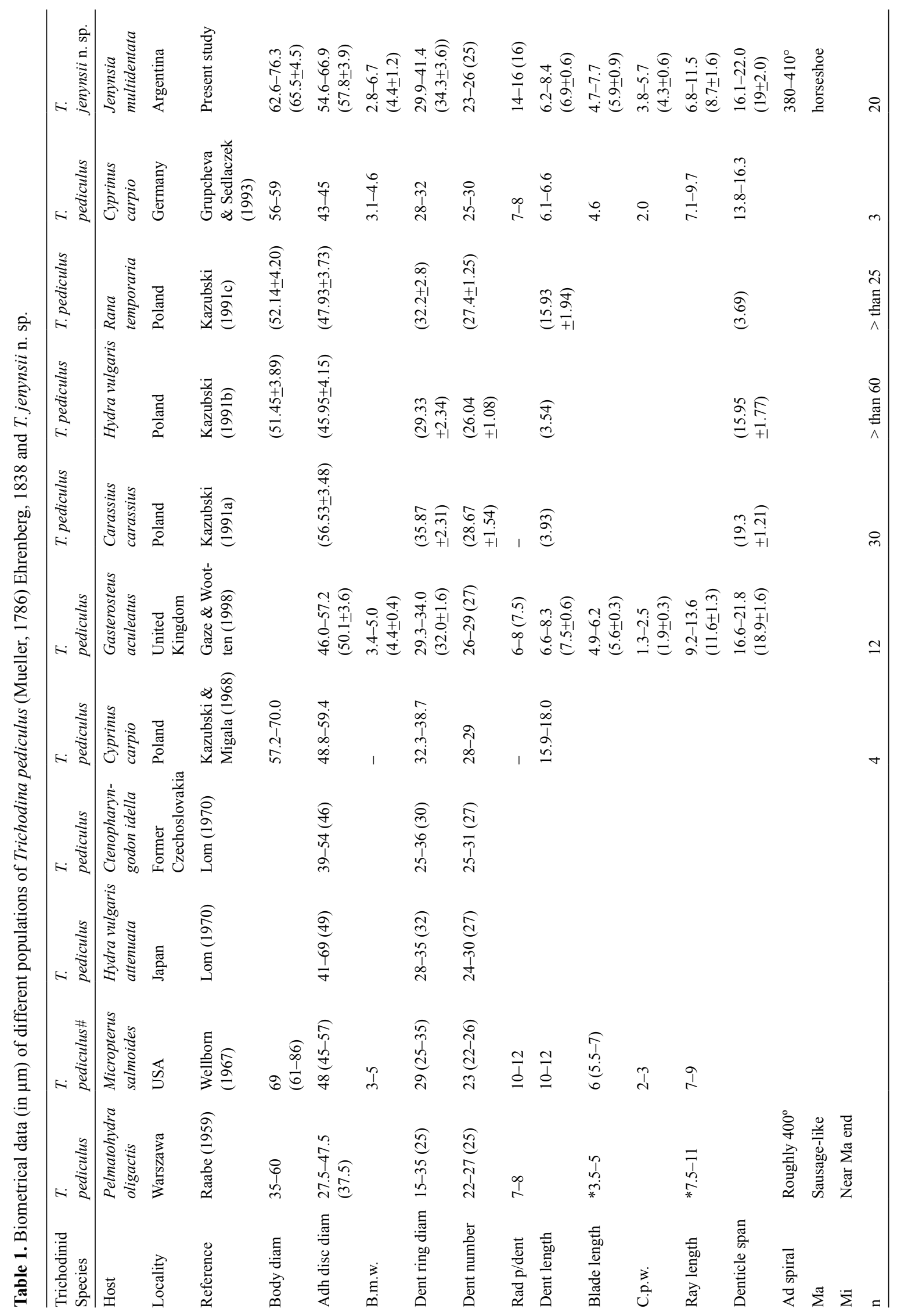


of the trichodinid identified as T. pediculus by Wellborn (1967). It appears to show a lot of similarities to another species described by this author, i.e. T. hypsilepis Wellborn, 1967. This is, however, a topic for another study.

The number of radial pins also differ markedly between $T$. pediculus and $T$. jenynsii, only provided in two cases for the former species, i.e. by Raabe (1959) and Grupcheva and Sedlaczek (1993), indicated as 7-8 in both instances. This represents half of the number found in T. jenynsii (14-16). Only the population provided by Wellborn (1967) comes close, but as stated previously, this trichodinid identification is in doubt.

The most important differences between T. pediculus and T. jenynsii can be found in the denticle shape (Figs 4C-F). According to Kazubski and Migala (1968) the denticle of T. pediculus have a longitudinal rib running along the ray in large specimens, this rib is clearly absent in $T$. jenynsii. Whilst $T$. jenynsii also characteristically have very long, tapering rays, as in T. pediculus, the denticles differ in the following features: T. pediculus typically has very slender central parts that do not always fit very tightly, fitting rather loosely into the preceding denticles. This can be seen in Kazubski and Migala (1968, Plate I, Nos. 1, 2), Kazubski (1991c, Figs 1, 2) and Gaze and Wooten (1998, Figs 3A, B). In the case of $T$. jenynsii the central part is shaped very differently, it is squat and very sturdy with the shape above and below the X-axis distinctly different. The tip of the central part also barely reaches the middle of the Y-1 axis, where-as in $T$. pediculus, the central part tip reached more than halfway to Y-1 axis. There is also a wide and prominent posterior projection that corresponds very closely with a distinct notch in the distal central part (central part above $\mathrm{X}$-axis), ensuring very tight-fitting denticles in the case of $T$. jenynsii. In T. pediculus the posterior projection, if visible, is weakly developed and does not correspond very closely to a notch in the central part above the X-axis, if it is indeed present.

In all silver-impregnated specimens of $T$. pediculus the blade connection is very delicate, where-as this connection is robust and large in $T$. jenynsii. Where the rays leave the central part in $T$. pediculus there is an obvious thickening, producing a very strongly developed ray connection that is in most cases as robust, but in some more robust than the width of the central part. In $T$. jenynsii the ray connection is robust, but never as stout as the very wide and squat central part. There is also a marked difference in the rays between these two species. Trichodina pediculus typically has very long rays, tapering to sharp thin points, almost meeting in the center in adult specimens. The rays in $T$. jenynsii tapers more gradually, are not nearly as long, never tapers to sharp points and never reaches as far into the center as do the rays of $T$. pediculus.

Lastly, the ratio of the denticle above to below the $\mathrm{X}$-axis also differs. In $T$. jenynsii this varies from 0.66-0.69. However, in T. pediculus this ratio varies from 0.46 for the population described by Raabe (1959) (indicated as $1: 2$, thus 0.5 by Raabe himself), 0.48 for T. pediculus described by Grupcheva and Sedlaczek (1993) and 0.58 for the population of Gaze and Wooten (1998), an indication that the ray is far longer than the blade in T. pediculus than is the case for T. jenynsii. For most of the other populations (see Table 1) this ratio cannot be calculated, as denticle dimensions were not provided.

It appears that while T. pediculus is supposedly the most well known of all trichodinid species, a well described population representing a large number of specimens is not available. Kazubski (1991a, b, c) provided some measurements for large populations from Hydra vulgaris, Rana temporaria tadpoles and Carassius carassius respectively, but provided only the length and width of the denticles and no other denticle dimensions. Large populations of $T$. pediculus from fish hosts appear to be scant, therefore a detailed description of this species from fish hosts is urgently required. Kazubski and Migala (1968), Grupcheva and Sedlaczek (1993) and Gaze and Wooten (1998) based their descriptions on very small numbers of $T$. pediculus on Cyprinus carpio (in first two reports) and Gasterosteus aculeatus (for the third) respectively (i.e. 4, 3 and 12 specimens measured respectively).

Very few recent studies have provided a description of the full nuclear apparatus, as a matter of fact only Raabe (1959) gives some indication of this; describing a sausage-shaped macronucleus, frequently irregular in thickness and terminally pointed, describing an arc of roughly $300^{\circ}$ and $\pm 16 \mu \mathrm{m}$ in diameter, with a micronucleus located near one of the end of the macronucleus. In the present study, no micronucleus was detected and the horseshoe-shaped macronucleus has an external diameter of 43.7-45.4 (44.5) $\mu \mathrm{m}$.

Acknowledgements. This work was funded by a fellowship grant from Consejo Nacional de Investigaciones Científicas y Tecnológicas (CONICET) to P. Marcotegui, and a research grant from La Plata National University (UNLP: N504) to S. Martorelli. 


\section{REFERENCES}

Cremonte F., Figueras A. (2004) Parasites as possible cause of mass mortalities of the presently critically endangered clam Mesodesma mactroides on the Southwest Atlantic coast. Bull. Eur. Assoc. Fish Pathol. 24: 166-171

Cremonte F., Figueras A., Burreson E. M. (2005) A histopathological survey of some commercially exploited bivalve molluscs in northern Patagonia, Argentina. Aquaculture 249: 23-33

Dove A. D. M., O’Donoghue P. J. (2005) Trichodinids (Ciliophora: Trichodinidae) from native and exotic Australian freshwater fishes. Acta Protozool. 44: 51-60

Foissner W. (1992) The dry silver nitrate method. In: Protocols in Protozoology (Eds. J. J. Lee and A. T. Soldo). Allen Press, Kansas, C 11.1-C11.3

Gaze W. H., Wootten R. (1999) An SEM study of adhesive disc skeletal structures isolated from trichodinids (Ciliophora: Peritrichida) of the genera Trichodina Ehrenberg, 1838 and Paratrichodina Lom, 1963. Syst. Parasitol. 43: 167-174

Gaze W. H., Wootten R. (1998) Ectoparasitic species of the genus Trichodina (Ciliophora: Peritrichida) parasitising British freshwater fish. Folia Parasit. 45: 177-190

Ghedotti M. J., Weitzman S. H. (1996) A new species of Jenynsia (Cyprinodontiformes: Anablepidae) from Brazil with comments on the composition and taxonomy of the genus. Occasional papers of the Natural History Museum. The University of Kansas. Lawrence 179: 1-25

Grupcheva G., Sedlaczek J. (1993) Some trichodinid ciliates (Ciliata: Urceolariidae) from common carp and sticklebacks in eastern Germany. J. Appl. Ichthyobiol. 9: 123-128

Hashimoto G. S. O., Marchiori N. C., Pádua S. B., Ishikawa M. M., Garcia J. R. E., Martins M. L. (2016) A new species of Trichodina Ehrenberg, 1830 (Ciliophora: Trichodinidae) from Rhamdia quelen (Siluriformes: Heptapteridae) and Gymnotus sp. (Teleostei: Gymnotidae) in Brazil. Acta Parasitol. 61: 707-712

Kazubski S. L, Migala K. (1968) Urceolariidae from breeding carp Cyprinus carpio L. in Zabieniec and remarks on the seasonal variability of trichodinids. Acta Protozool. 6: 137-160

Kazubski S. L. (1991a) Morphological variation of the ciliate Trichodina pediculus Ehrenberg, 1838. I. Parasitising hydras. Acta Protozool. 30: 169-175

Kazubski S. L. (1991b) Morphological variation of the ciliate Trichodina pediculus Ehrenberg, 1838. II. Parasitising on tadpoles. Acta Protozool. 30: 177-186

Kazubski S. L. (1991c) Morphological variation of the ciliate Trichodina pediculus Ehrenberg, 1838. III. Parasitising on crucian carp (Carassius carassius (L.) from small ponds in Kortowo (Olsztyn). Acta Protozool. 30: 187-192

Lom J. (1970) Trichodinid ciliates (Peritrichida: Urceolariidae) from some marine fishes. Folia Parasitol. 17: 113-125
Lom J. (1958) A contribution to the systematics and morphology of endoparasitic trichodinids from amphibians, with a proposal of uniform specific characteristics. J. Eukaryot. Microbiol. 5: 251-263

Lom J., Haldar D. P. (1976) Observations on trichodinids endocommensal in fishes. Trans. Amer. Microsc. Soc. 95: 527-541

Marcotegui P. S., Martorelli S. R. (2009) Trichodinids (Ciliophora: Peritrichida) of Mugil platanus (Mugiliformes: Mugilidae) and Micropogonias furnieri (Perciformes: Sciaenidae) from Samborombon Bay, Argentina with the description of a new species. Folia Parasitol. 56: 167-172

Martins M. L., Ghiraldelli L. (2008) Trichodina magna Van As and Basson, 1989 (Ciliophora: Peritrichia) from cultured Nile tilapia in the state of Santa Catarina, Brazil. Braz. J. Biol. 68: 177-180

Martorelli S., Marcotegui P., Alda M. (2008) Trichodina marplatensis n. sp. (Ciliophora: Trichodinidae) from Combjelly, Mnemiopsis mccradyi (Mayer, 1900) in Argentine Sea. Acta Protozool. 47: 257-261

Miranda H., Marchiori L., Rebaza Alfaro C., Martins M. L. (2012) First record of Trichodina heterodentata (Ciliophora: Trichodinidae) from Arapaima gigas cultivated in Peru. Acta Amazonica 42: $433-438$

Raabe Z. (1959) Urceolariidae of gills of Gobiidae and Cottidae from Baltica Sea. Acta Parasitol. Polon. 7: 441-452

Tavares-Dias M., da Costa Marchiori N., Martins M. (2013) Paratrichodina africana (Ciliophora: Trichodinidae) of wild and cultured Nile tilapia in the Northern Brazil. Rev. Bras. Parasitol. Vet. 22: 248-252

Van As J. G., Basson L. (1989) A further contribution to the taxonomy of the Trichodinidae (Ciliophora: Peritrichia) and a review of the taxonomic status of some fish ectoparasitic trichodinids. Syst. Parasitol. 14: 157-179

Van As J. G., Basson L. (1992) Trichodinid ectoparasites (Ciliophora: Peritrichida) of freshwater fishes of the Zambesi River System, with a reappraisal of host specificity. Syst. Parasitol. 22: 81-109

Viozzi G. (1996) Presencia de protozoos parásitos de peces autóctonos de Patagonia Argentina. Bol. Chil. Parasitol. 51: 32-34

Wellborn T. L. (1967) Trichodina (Ciliata: Urceolariidae) of freshwater fishes of the southeastern United States. J. Protozool. 14: 399-412

Yemmen C., Quilichini Y., Hédi Ktari M., Marchand B., Bahri S. (2010) Morphological, ecological and histopathological studies of Trichodina gobii Raabe, 1959 (Ciliophora: Peritrichida) infecting the gills of Solea aegyptiaca. Protistology 6: 258-263

Received on $8^{\text {th }}$ November, 2016; revised on $15^{\text {th }} 2016$; accepted on $16^{\text {th }}$ December, 2016 